\title{
Guillevic. L'Été.
}

Marseille: Editions Autres Temps, 1994.104 pages. 80FF.

$W_{\text {consciousness, Guillevic's } L^{\prime} \text { tóté gives in a self-reflexive fusing of matter and }}^{\text {ords and whiteness vime simultaneously frag- }}$ mented and gathering into its teeming multiplicities, real, metaphorical, dreamed, caught between relativity and what Reverdy called justesse. Each of summer's textual quanta is the sign of a desire for a fullness, a blossoming, that, curiously, Guillevic feels to be most available via a compacting and telescoping of language wherein meaning, the logic of being, of what has been l'été can rhythmically dilate and contract in a kind of ever pregnant, richly inviting minimalism. L'Été is at once the poem of summer, a discourse upon its tangible and intangible textures and folds, its traversal of us, our reading of its transparencies and its opaqueness, and the poem as summer, lived, thought, felt, yet experienced as time, becomingness, moving between a sense of possession and a knowledge of dispossession, between a luxuriance and absence, summer's being welling up into words and simultaneously, via the very words mots-morts, said Bernard Noël - that memorialize it, ebbing ineluctably into non-being, mere been-ness. There is, of course, in this delightfully characteristic book, much discreet emotion, much thoughtful unpretentiousness, a desire, one feels, to leap through language's strange mirror into the very exquisite mystery of the ontos that, forever, has haunted Guillevic and understandably made him, at a wonderful age, the poet of darting youthfulness and shining simplicity. "Le sort de l'été," Guillevic rightly affirms, "ne paraissait pas écrit." Here, to conclude, is one of the closing quanta of a book that, in telling so deftly, recognises that thought's action leaves miraculously undisturbed the "fate" of what it writes:

Si je portais

ce que j'avais rêvé,

me resterait à devoir inventer 
la fin de l'été

mais il n'y a que l'eté

pour en finir avec l'été.

Guillevic, ever-cherishable, ever gently surprising.

Michael Bishop

Dalhousie University 